\title{
Panel offers compromise on food labelling
}

Paris. The group that advises the European Commission on ethical questions related to be labelled to indicate when its composition and characteristics have been "substantially modified" by genetic engineering techniques. But it says such labelling is "inappropriate" when changes are insubstantial.

The recommendation conflicts with the position taken by the commission itself in a draft directive on novel foods, which opposes systematic labelling on the grounds that it would "tend to stigmatize biotechnology" while providing little useful information to the consumer. That is also the general position endorsed by the US Food and Drug Administration (FDA) in 1992.

The ethics advisory group, set up to help the commission deal with divisive issues raised by genetic engineering, was itself divided, and the final 'opinion', accepted unanimously by the group's members and published last month, is a compromise.

It endorses current regulatory thinking that the safety of products should be "scientifically assessed and assured". But it also says that, exceptionally, consumer demand for information about biotechnology justifies labels indicating the process used, even though - in an attempt to avoid stigmatizing biotechnology - it argues that such labelling should be restricted to cases involving "substantial change".

The Brussels-based Confederation of the Food and Drink Industries wants novel foods labelled only where a change in composition has substantially altered either a food's nutritional value or the way it is metabolized in the body.

But the ethics group's recommendation has been welcomed by the UK pharmaceutical company Zeneca - formerly part of ICI biotechnology has recommended that food

- which markets a tomato that has been genetically engineered to delay softening. "It's all about choice", says Nigel Poole, regulatory affairs manager at Zeneca. Telling a consumer that he or she does not need certain information will only raise suspicion, says Poole. "We are going to inform the consumer; we are proud of our tomato."

Zeneca's position reflects a growing trend among those using genetic engineering techniques in food production to introduce labelling in response to consumer demand, rather than regulation. Indeed, Poole, in common with others in the industry, feels that the heated debate over whether such food should be specifically labelled will eventually subside as more such products arrive on supermarket shelves, and consumers increasingly judge them on their nutritional and culinary merits.

For example, although 1,500 US chefs have agreed not to serve genetically engineered food (see Nature 359, 8; 1992), Calgene's Flavr Savr tomato is reported to be selling well in the United States, as is a vegetarian cheese produced by the UK Cooperative and Wholesale Society which is based on recombinant chymosin - and voluntarily labelled as such.

This trend appears to be confirmed by the fact that almost half of those interviewed in a survey carried out by the Dutch consumer research institute SWOKA said that they did not need to be informed that a food had been produced by genetic engineering techniques, providing it had been approved by a regulatory authority.

A further quarter said merely that they would like to know when such foods came on to the market. Only one-fifth wanted biotechnology foods to be specifically identified on their label.

\section{Curtain descends on CSIRO dispute}

Sydney. A bitter dispute between scientists and senior management at Australia's Commonwealth Scientific and Industrial Research Organisation (CSIRO), has been settled - but not before questions had been raised by members of a parliamentary committee whose inquiry last year strongly criticized CSIRO management.

Senator Alan Ferguson, who headed the inquiry, said last week that he had received a very "non-committal" answer from Peter Cook, the Minister for Science, about problems in the CSIRO. But he added that the acting head of CSIRO, Roy Green, had agreed that there would be no repetition of the incident that sparked the dispute.

In that incident, the chiefs of five CSIRO divisions - its major operating unit - had each read a letter to their respective staffs apologizing to the CSIRO board for using the phrase "conflict of interest" in comments submitted by the staffs on an internal management report (see Nature 375, 268; 1995).

Although staff say they were referring to the fact that all board members (apart from Green) also work for other organizations, the board is said to have interpreted the phrase as complaining of financial conflict. But the board's response led to staff accusations that the chiefs had been forced to apologize.

According to Ferguson, Green has now agreed to work directly with staff on the organization's problems, particularly on CSIRO's structure and management, and its internal communications. In return, he and other members of the parliamentary committee have agreed not to reopen last
Mark Lawson year's inquiry.

\section{IMAGE \\ UNAVAILABLE \\ FOR COPYRIGHT REASONS}

Genetically-engineered potatoes: should they carry labels detailing techniques used?

Many in the food industry attribute part of the controversy over genetically engineered foods to the "unfortunate" fact that one of the first products to come to market was milk produced using bovine somatotropin (BST), which offered clear advantages to large dairy farmers - but not to consumers. "We started off down the wrong track with BST," says one official of the European Commission.

At the same time, others argue that the recommendations of the ethics group, which draw on assumptions about the consumers' 'right to know', beg the question of the extent to which governments should give precedence to the opinions of vocal pressure groups over 'scientific soundness' in handling complex technological issues.

Claims for the 'right to know' are both seductive and difficult to counter, as the alternative appears to be self-regulation by an unaccountable élite. But, says one critic, the concept is "misleading and simplistic".

Labelling, he argues, could require the publication of information considered irrelevant by regulatory authorities to genuine concern about safety, by potentially causing anxiety among consumers. By highlighting foods produced by biotechnology, pressure groups can create anxiety over a "non-issue" he argues, and stigmatize such products.

The ethics group has apparently rejected this argument. But its recommendations may be unenforceable. Flour, for example, may be ground from several silos, each holding wheat from several farms.

One commission official adds that, if one process is to require labelling, then logically other processes should be identified on food labels as well. Rather than labelling milk as having being produced using BST, he argues, might it not be more important to mention which herbicide was sprayed on the meadow the week before the cow was milked? How long, he asks, can a label be? Declan Butler 